\title{
Intraoperative injection of absorbable gelatin sponge (AGS) mixed with cement followed by spinal decompression to treat elderly with vertebral hemangiomas
}

\author{
Weihong $\mathrm{Xu}^{1+}$, Zhibin $\operatorname{Lan}^{2+}$ (1) and Yuming Huang ${ }^{3^{*}}$ (D)
}

\begin{abstract}
Background: Elderly patients with vertebral hemangiomas are rare and might require surgery. Thus, the choice of surgery for these lesions remains controversial because of the rarity of these lesions. This study aimed to analyze the clinical efficacy of the intraoperative injection of absorbable gelatin sponge mixed with cement followed by spinal decompression to treat the elderly with typical vertebral hemangiomas. The risk factors for hemangioma recurrence were investigated through a literature review.
\end{abstract}

Methods: We retrospectively analyzed 13 patients with typical aggressive hemangiomas between January 2009 and January 2016. Of these patients, 7 were treated with spinal decompression combined with intraoperative vertebroplasty (Group A), and 6 patients were treated with decompression with intraoperative vertebroplasty and absorbable gelatin sponge (Group B). The general data and perioperative data of the patients were compared. Patients were followed up for at least 3 years, and postoperative complications and recurrence rates were recorded and compared.

Results: All patients had typical aggressive hemangiomas. The average age of all patients was $64.4 \pm 3.3$ years. The preoperative data did not differ significantly between the two groups $(P>0.05)$. The blood loss of groups $A$ and $B$ was $707.1 \pm 109.7 \mathrm{ml}$ and $416.7 \pm 103.3 \mathrm{ml}$, respectively $(P=0.003)(P=0.003)$, and the average surgery durations were $222 \pm 47.8 \mathrm{~min}$ and $162 \pm 30.2 \mathrm{~min}$, respectively $(P=0.022)$. The average follow-up duration was $62 \pm 19$ months, and no cases of recurrence were found at the final follow-up assessment.

Conclusions: Multimodal treatment significantly alleviated the clinical symptoms of elderly patients with typical aggressive vertebral hemangiomas. Intraoperative absorbable gelatin sponge injection is a safe and effective way to reduce blood loss and surgery duration.

Keywords: Aggressive vertebral hemangiomas, Pain, Multimodal surgery, Absorbable gelatin sponge

\section{Background}

A vertebral hemangioma is a benign tumor. Anatomical and imaging studies have shown that the incidence of vertebral hemangiomas ranges from 10 to $26 \%$; most cases are asymptomatic, and only $0.9-1.2 \%$ of affected

\footnotetext{
* Correspondence: 1143810401@qq.com

'Weihong Xu and Zhibin Lan are co-first authors.

${ }^{3}$ The Orthopedics Department, Fuzhou Second Hospital affiliated to Xiamen

University, Cangshan District, Fuzhou 350007, Fujian, China

Full list of author information is available at the end of the article
}

individuals have clinical symptoms [1, 2]. Pathologically, a hemangioma is composed of benign vascular dysplasia or vascular lumen and endothelial cells. These lesions are usually localized to one of three anatomical locations: on the periosteal surface, within the cortex, or within the medullary canal [3]. On imaging, the spinal vertebral body typically manifests as fence-, grid-, and honeycomb-like changes to the vertebral body $[4,5]$. Currently, a vertebral hemangioma is classified using the following three stages of the Enneking system: (1) during latency, the tumor is restricted within the spinal 
compartment (Enneking stage 1; S1); (2) during the active stage, the tumor is contained within the spinal compartment and is accompanied by clinical symptoms (Enneking stage 2; S2); and (3) during the aggressive stage, the tumor expands out of the spinal compartment and is accompanied by clinical symptoms (Enneking stage 3; S3) [1].

Because S3 stage hemangiomas are rare with a high recurrence rate, simple surgical approaches remain controversial. Some experts $[6,7]$ recommended simple spinal decompression or tumor reductive surgery, which has low technical surgery requirements, causes little intraoperative blood loss, and is associated with fast postoperative recovery. However, the high recurrence rate leads to poor clinical prognosis $[2,8-11]$. Therefore, some authors have proposed en bloc resection for vertebral hemangiomas [3, 12]. According to the currently available data, no tumor recurrence has been found after en bloc resection. However, the intraoperative blood loss is far more than that of decompression, and the incidence of bleeding-related complications after surgery is significantly increased. Furthermore, this procedure not only demands surgical skill but also requires patients with higher health statuses [12]. Thus, some experts have recently studied multimodal treatments for aggressive hemangiomas [13-16]. Multimodal treatments include preoperative interventional embolization, spinal canal decompression or en bloc.

Vertebral hemangiomas are common among people $40-50$ years of age but are relatively rare among elderly patients (> 60 years old). To the best of our knowledge, no study has analyzed the treatment of elderly patients with typical S3 hemangiomas. Therefore, we evaluated the clinical efficacy and long-term recurrence rate of the multimodal treatment of elderly patients with S3 hemangiomas and investigated whether the intraoperative injection of absorbable gelatin sponge affected bleeding or relevant complications.

\section{Methods}

After approval by the ethics committee, we retrospectively analyzed the cases of elderly patients with typical S3 hemangiomas ( $>60$ years old) undergoing surgery at our hospital between January 2009 and January 2016. We consecutively recruited 13 patients and tracked their progression for at least 3 years. Seven patients were treated with spinal decompression combined with intraoperative vertebroplasty (Group A), and six patients were treated with absorbable gelatin sponge combined with decompression and vertebroplasty (Group B) since 2013. All procedures were performed by one spinal surgeon.

Experienced spinal surgeons collected general patient information (including sex, age, medical history, tumor level, fusion level, body mass index (BMI), main clinical symptoms, and symptom duration). The Frankel grade classification was used to assess neurologic status. Back pain was assessed using a visual analogue scale (VAS). The perioperative data included surgical procedure, intraoperative blood loss, surgery duration, postoperative hospital stay duration, presence of complications, and postoperative pathology.

\section{Imaging and biopsy}

All patients received preoperative lateral standing radiographs, computed tomography $(\mathrm{CT})$ scans, and magnetic resonance imaging (MRI) of the spine. Typical imaging manifestations included "honeycomb" and "corduroy" signs on CT and thickened trabecular bone on the cross-section in the form of a dot. MRI examinations showed low T1 signal/high T2 signal changes in the affected spine (Fig. 1). Lateral standing radiographs and MRI imaging of the spine were taken immediately after surgery. Lateral radiographs of the spine were taken 3 months after surgery and during the follow-up period to confirm and determine the status of the implants.

\section{Surgical decisions}

Surgery was usually performed for patients with typical S3 hemangiomas to alleviate their clinical symptoms. Surgical decompression was the primary option for elderly patients, regardless of whether the tumor invaded the surrounding soft tissue. The spine was stabilized with 4 or 8 pedicle screws depending on the bone condition (8 pedicle screws for severe osteoporosis patients). In this study, we performed preoperative embolization for all patients undergoing S3 hemangioma surgery to reduce intraoperative blood loss. We injected cement through the unilateral pedicles of the vertebral arch for all patients (a unilateral pedicle approach was first considered). Postoperative radiotherapy was not performed for elderly patients.

\section{Surgical methods}

A posterior median incision centered on the affected spinous process was made to expose 1-2 vertebral joints above and below the vertebral plates. Then, the pedicles of the vertebral arch were punctured under direct visualization guided by $\mathrm{C}$-arm fluoroscopy. Pre-prepared $1.0 \mathrm{~mm} \times 1.0 \mathrm{~mm} \times 1.0 \mathrm{~mm}$ absorbable gelatin sponge (Jinling Pharmaceutical Co., Ltd., Nanjing, China) particles were mixed with the contrast agent and injected into the affected spines of patients in group B, and 6 8 $\mathrm{ml}$ viscous cement was used to fill the affected spine under visualization guided by $\mathrm{C}$-arm fluoroscopy. The puncture needle was withdrawn after the cement solidified. Patients in group A were only injected with cement, and the remaining procedure was the same. The lesion 

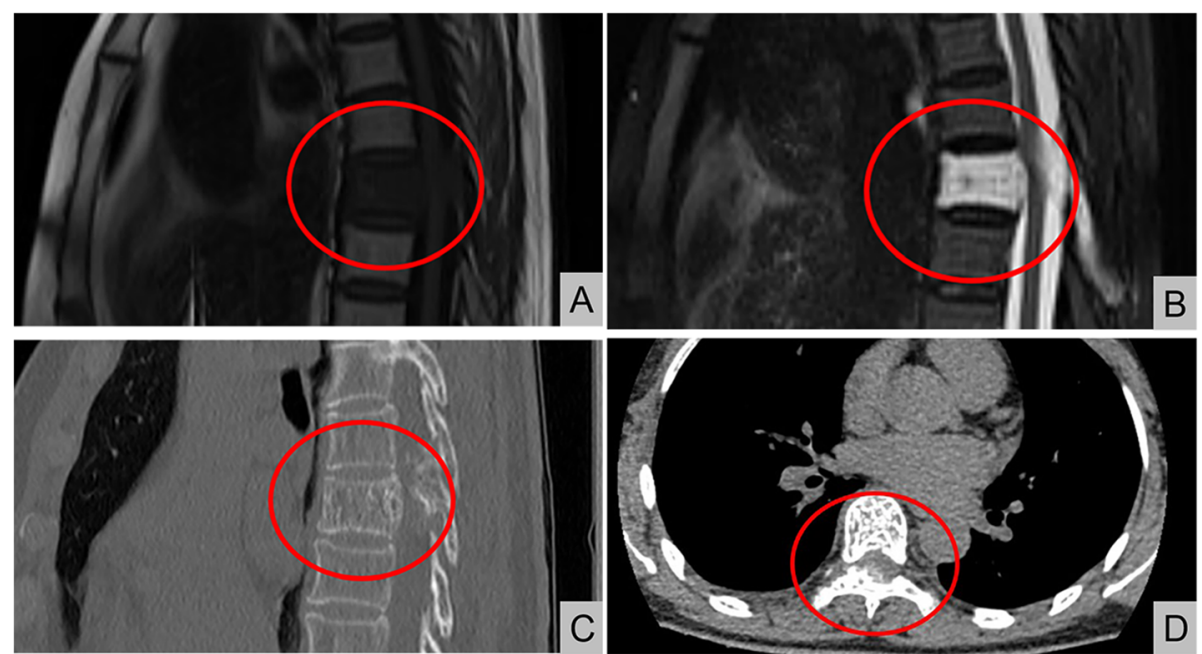

Fig. 1 A 69 year-old female patient who had a T7 hemangiomas (typical MRI and CT scans)

and entire vertebral body needed to be packed without bone cement leakage to destroy and shrink the malformation. Because bone cement can release energy during expansion, the local temperature reaches 80-90 degrees Celsius, and the diseased site can shrink. Then, direct decompression of the lesion (laminectomy) was performed to remove the invasive hemangiomas. (Fig. 2).

\section{Statistical analyses}

All data were analyzed using SPSS 23.0 (SPSS Inc., Chicago, IL). The Kolmogorov-Smirnov test was performed to determine if the data were normally distributed. Normally distributed data are presented as the means \pm standard deviations. Nonnormally distributed data are represented as medians and ranges. Significant differences in data between groups were determined via independent sample $\mathrm{U}$-tests and t-tests. $P<0.05$ was considered significant.

\section{Results}

A total of 13 elderly patients (four men and nine women) were recruited for this study, with an average age of $64.4 \pm 3.3$ years. Twelve cases of aggressive hemangioma were in the thoracic vertebra, and one was in the lumbar vertebra. One patient had multiple hemangiomas (T2, T10), and only the patient with a hemangioma at $\mathrm{T} 2$ underwent decompression treatment. The T10 tumor was asymptomatic and was only subjected to percutaneous vertebroplasty. Ten patients reported back pain with a VAS score of 6 points $(6-8$ points). Five patients had myelopathic symptoms (four patients had Frankel grade D, and one patient had Frankel grade $\mathrm{C}$ ). Two patients had radicular symptoms,

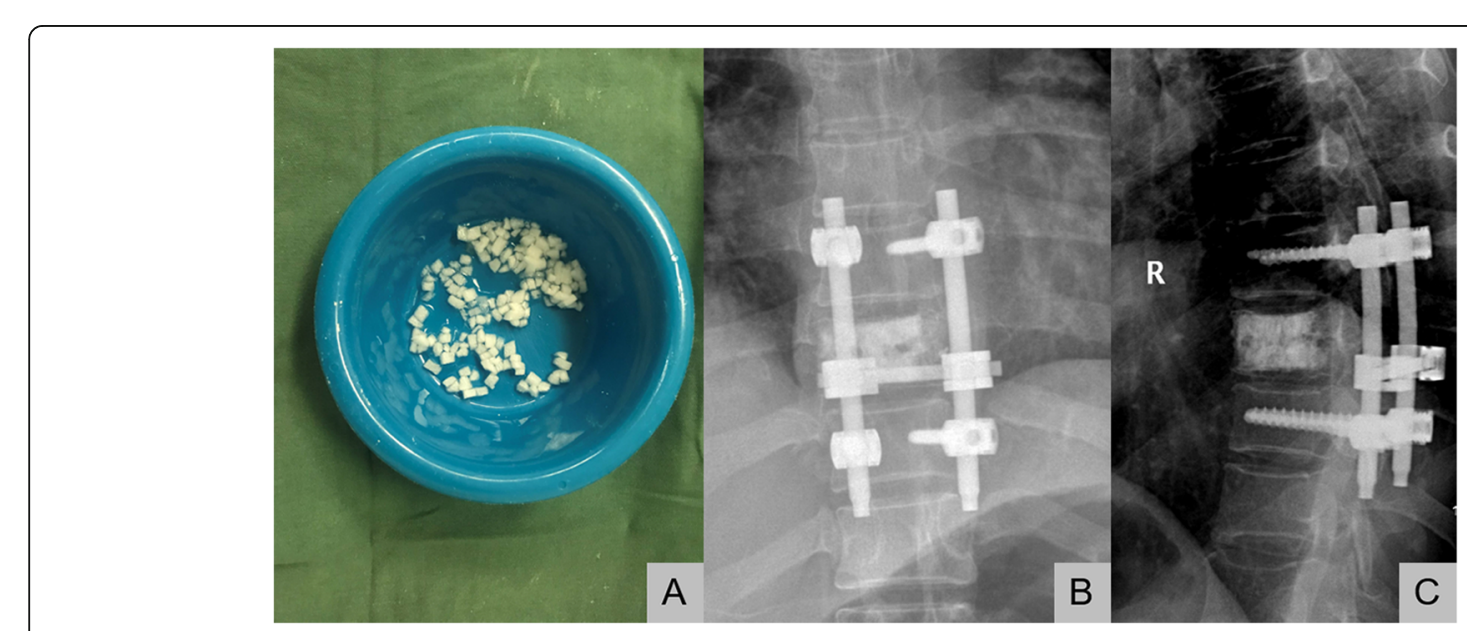

Fig. 2 Photograph showing pre-prepared $1 \mathrm{~mm} \times 1 \mathrm{~mm} \times 1 \mathrm{~mm}$ AGS particles mixed with the contrast agent and C-arm fluoroscopy photograph of a 69-year-old woman who underwent decompression and intraoperative vertebroplasty with absorbable gelatin sponge 


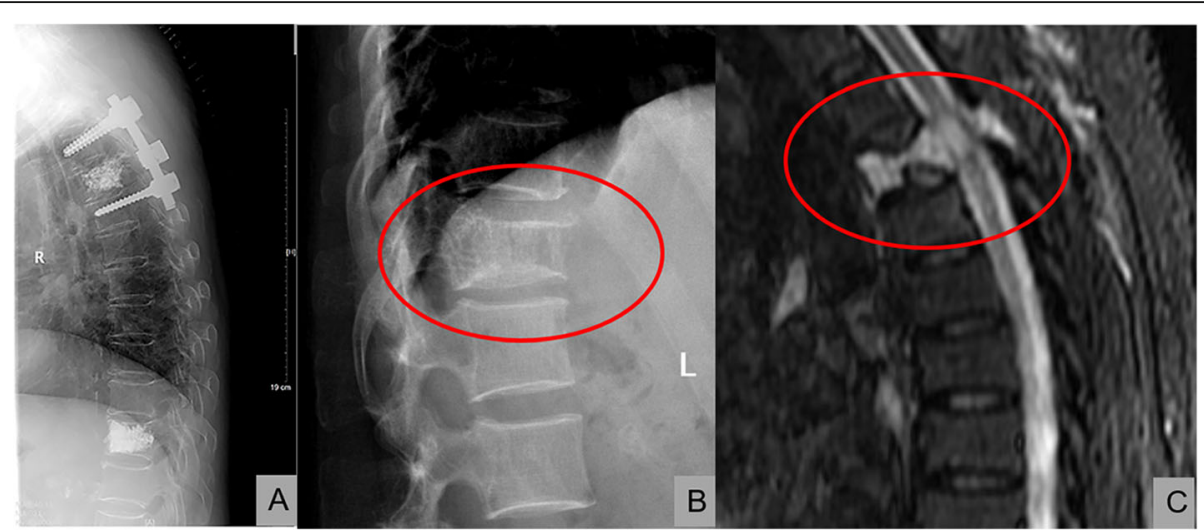

Fig. 3 a shows a 62-year-old male patient who had multiple hemangiomas (T2, T10), and the hemangioma at T2 underwent decompression and intraoperative vertebroplasty. The T10 tumor only underwent vertebroplasty. b and $\mathbf{c}$ show a 62 -year-old female patient who had pathological fractures at T4

and seven patients had pathological fractures. Two cases involved the bilateral pedicles, and 11 only involved the unilateral pedicles. Twelve cases involved the vertebral canal, and the tumors of three patients spread to the surrounding soft tissue. Two patients who underwent preoperative CT biopsy confirmed that they had hemangiomas. The preoperative data of the two groups of patients did not differ significantly $(P<0.005)$ (Fig. 3$)$.

The general and perioperative data are shown in Tables 1 and 2 .

\section{Surgical comparisons}

The average intraoperative blood loss and surgery duration differed significantly between the two groups $(P=0.003$ and 0.022 , respectively; Table 3$)$.

Because of the large amount of intraoperative blood loss, two patients in group A were infused with $4 \mathrm{U}$ of suspended red blood cells during surgery. One patient in group B had a large amount of postoperative drainage due to abnormal blood coagulation and was infused with $200 \mathrm{ml}$ of fresh frozen plasma to improve coagulation. The drain was removed within 2-4 days. No complications occurred. Postoperative pathology tests confirmed that all patients had hemangiomas.

\section{Follow-up period}

All patients were followed up clinically for an average of $62 \pm 19$ months. Because intraoperative injections of absorbable gelatin sponge were implemented in 2013, the average follow-up duration of group A patients was $76 \pm$ 12 months, and the average follow-up duration of group B patients was $46 \pm 7$ months. No myelopathic or radiculopathic symptoms were observed at the follow-up assessment (Frankel grade E). The VAS score was 1 point (0-2 pints), which was significantly lower than that prior

Table 1 General data

\begin{tabular}{|c|c|c|c|c|c|c|c|}
\hline No. & Age(y) & $\mathrm{CDH}$ & tumor Level & Fusion Levels & symptoms & $\mathrm{BMl}$ & Symptom duration (mo) \\
\hline 1 & 63 & - & T8 & T7-9 & Pain & 19.5 & 5 \\
\hline 2 & 66 & $\mathrm{HBP}$ & T3 & $\mathrm{T} 1-5$ & Pain, myelopathy & 20.0 & 1 \\
\hline 3 & 62 & - & $\mathrm{T} 10, \mathrm{~T} 2$ & T9-11 & Pain, myelopathy & 22.0 & 12 \\
\hline 4 & 61 & $\mathrm{HBP}$ & $\llcorner 4$ & L3-5 & Radiculomyelopathy & 24.2 & 36 \\
\hline 5 & 68 & DM & $\mathrm{T} 12$ & T11-L1 & Radiculomyelopathy & 23.3 & 3 \\
\hline 6 & 71 & - & T6 & T5-7 & Pain & 20.0 & 24 \\
\hline 7 & 65 & - & T4 & T3-5 & Pain, myelopathy & 19.9 & 6 \\
\hline 8 & 69 & - & T7 & T5-9 & Pain & 17.5 & 30 \\
\hline 9 & 65 & $\mathrm{HBP}$ & $\mathrm{T} 12$ & T11-L1 & Radiculomyelopathy & 19.9 & 12 \\
\hline 10 & 62 & - & $\mathrm{T7}$ & T6-8 & Pain, myelopathy & 20.2 & 3 \\
\hline 11 & 61 & - & T3 & $\mathrm{T} 2-4$ & Pain & 25.0 & 9 \\
\hline 12 & 62 & DM & T4 & T3-5 & Pain, myelopathy & 24.0 & 6 \\
\hline 13 & 62 & - & T3 & T2-4 & Pain & 21.7 & 9 \\
\hline
\end{tabular}

Abbreviations: $C D H$ chronical diease history, $H B P$ high blood pressure, $D M$ diabetes mellitus, $B M I$ body mass index 
Table 2 Perioperative data

\begin{tabular}{|c|c|c|c|c|c|c|c|c|c|c|}
\hline No. & TA & $\begin{array}{l}\text { quantity of VP } \\
(\mathrm{ml})\end{array}$ & Group & $\begin{array}{l}\text { blood loss } \\
(\mathrm{ml})\end{array}$ & $\begin{array}{l}\text { surgery time } \\
(\mathrm{min})\end{array}$ & $\begin{array}{l}\text { Time to discharge after } \\
\text { surgery (d) }\end{array}$ & $\begin{array}{l}\text { blood } \\
\text { transfusion }\end{array}$ & $\begin{array}{l}\text { Pre- } \\
\text { Frankel }\end{array}$ & $\begin{array}{l}\text { Pre- } \\
\text { VAS }\end{array}$ & Complication \\
\hline 1 & Y & 6 & $\begin{array}{l}\text { Group } \\
\text { A }\end{array}$ & 700.0 & 120 & 7 & & - & 9 & - \\
\hline 2 & Y & 6 & $\begin{array}{l}\text { Group } \\
\text { A }\end{array}$ & 800.0 & 240 & 8 & $\mathrm{RBC} 4 \mathrm{u}$ & D & 8 & - \\
\hline 3 & Y & 6 & $\begin{array}{l}\text { Group } \\
\text { A }\end{array}$ & 650.0 & 140 & 7 & & D & 8 & - \\
\hline 4 & Y & bilateral 3 & $\begin{array}{l}\text { Group } \\
\text { A }\end{array}$ & 900.0 & 300 & 10 & $\mathrm{RBC} 4 \mathrm{u}$ & - & - & - \\
\hline 5 & Y & 7 & $\begin{array}{l}\text { Group } \\
\text { A }\end{array}$ & 600.0 & 240 & 7 & & - & - & - \\
\hline 6 & Y & 6 & $\begin{array}{l}\text { Group } \\
\text { A }\end{array}$ & 700.0 & 200 & 10 & & - & 7 & - \\
\hline 7 & Y & 8 & $\begin{array}{l}\text { Group } \\
\text { A }\end{array}$ & 600.0 & 240 & 7 & & D & 6 & - \\
\hline 8 & Y & 6 & $\begin{array}{l}\text { Group } \\
\text { B }\end{array}$ & 550.0 & 200 & 7 & FFP $200 \mathrm{ml}$ & C & 6 & - \\
\hline 9 & Y & 7 & $\begin{array}{l}\text { Group } \\
\text { B }\end{array}$ & 300.0 & 130 & 7 & & - & - & - \\
\hline 10 & Y & 6 & $\begin{array}{l}\text { Group } \\
\text { B }\end{array}$ & 450.0 & 150 & 10 & & D & 7 & - \\
\hline 11 & Y & 7 & $\begin{array}{l}\text { Group } \\
\text { B }\end{array}$ & 500.0 & 150 & 7 & & - & 6 & - \\
\hline 12 & Y & 6 & $\begin{array}{l}\text { Group } \\
\text { B }\end{array}$ & 400.0 & 120 & 9 & & D & 6 & - \\
\hline 13 & Y & 7 & $\begin{array}{l}\text { Group } \\
\text { B }\end{array}$ & 300.0 & 160 & 7 & & - & 6 & - \\
\hline
\end{tabular}

Abbreviations: Group A decompression combined with intraoperative vertebroplasty, Group B decompression combined with intraoperative vertebroplasty and absorbable gelatin sponge, $T A$ transarterial embolization, $Y$ yes, $R B C$ red blood cell, FFP fresh freezing plasma, VAS Visual analogy score, Pre- preoperative

to the surgery $(P<0.05)$. No patients had tumor recurrence at the last follow-up assessment.

\section{Discussion}

Typical S3 hemangiomas can cause spinal cord compression, bone destruction, and neurological damage. Because of the small number of cases, no consensus exists concerning the gold standard to treat S3 hemangiomas. Currently, the reported treatments for vertebral hemangiomas include radiotherapy [17], interventional embolization [18], alcohol ablation [19, 20], vertebroplasty [21], and surgery [2, 3, 8]. Cloran et al. [4] believed that physicians should attend to symptomatic

Table 3 Comparisons between operations

\begin{tabular}{lllll}
\hline Factors & Group A & Group B & $t$ & $P$ \\
\hline Blood loss (ml) & $707.1 \pm 109.7$ & $416.7 \pm 103.3$ & 4.889 & 0.003 \\
Surgery time (min) & $222 \pm 47.8$ & $162 \pm 30.2$ & 2.658 & 0.022 \\
Discharge (d) & $15 \pm 1.5$ & $17.0 \pm 3.4$ & 0.219 & 0.831
\end{tabular}

Abbreviations: Group A decompression combined with intraoperative vertebroplasty, Group $B$ decompression combined with intraoperative vertebroplasty and absorbable gelatin sponge, VP vertebroplasty, AGS absorbable gelatin sponge; hemangiomas and that multimodal treatments should be used for patients with S3 hemangiomas, which includes preoperative interventional embolization, spinal canal decompression or en bloc. We started thinking about an absorbable gelatin sponge to reduce the amount of bleeding from 2013. Since there was less bleeding, we maintained a clear field of vision and enabled complete removal of the abnormal tissue during the procedure. This was the first study to apply multimodal treatments for elderly patients with aggressive hemangiomas to investigate their postoperative efficacy and intraoperative complications and reported the clinical efficacy of absorbable gelatin sponge infusion during spinal decompression surgery.

In this study, we performed preoperative embolization for all patients undergoing S3 hemangioma surgery to reduce intraoperative blood loss. Robinson et al. [22] compared the intraoperative blood loss of patients who underwent preoperative embolization with that of those who did not undergo preoperative embolization and found that preoperative embolization significantly reduced intraoperative blood loss. Other additional factors, including anesthesia, surgical skill, and patient coagulation, might also 
cause intraoperative blood loss. As early as 1972, Hekster et al. [18] reported that preoperative embolization effectively reduced intraoperative blood loss and blood loss-related complications. In this study, all elderly patients underwent preoperative embolization; after surgery, no patients had blood loss-related complications. These findings are consistent with the literature reviewed above.

Acora et al. [3] believed that en bloc resection was required for patients with tumors that spread outside of the vertebral body, which significantly reduced tumor recurrence. The main advantage of en bloc resection was the low recurrence rate; however, some experts selected this method with hesitation because of the large amount of intraoperative blood loss, high technical requirements, and multiple complications. The study of Tomita et al. [12] and Ogawa et al. [23] revealed that the treatment of aggressive hemangiomas via radical resection was time consuming, leading to a large amount of blood loss. Even after preoperative embolization, the intraoperative blood

Table 4 Summary of the management and recurrence of patients with vertebral hemangioma

\begin{tabular}{|c|c|c|c|c|c|c|c|c|c|c|}
\hline Authors & No. & Age & $\begin{array}{l}\text { Tumor } \\
\text { types }\end{array}$ & Symptom & $\begin{array}{l}\text { Tumor } \\
\text { level }\end{array}$ & Treatment & $\begin{array}{l}\text { FU } \\
(y)\end{array}$ & $\begin{array}{l}\text { Recurrence } \\
\text { (y) }\end{array}$ & $\begin{array}{l}\text { Blood } \\
\text { loss } \\
(\mathrm{ml})\end{array}$ & $\begin{array}{l}\text { Risk factors of } \\
\text { recurrence }\end{array}$ \\
\hline \multirow{3}{*}{$\begin{array}{l}\text { Acosta et al. } \\
(2008)[2]\end{array}$} & 8 & 72 & $\mathrm{S3}$ & Pain, Myelopathy & $\mathrm{T} 5$ & TA & 20 & 2.4 & & \\
\hline & 9 & 44 & $\mathrm{S3}$ & Radiculopathy & T11、 T12 & decompression & 12 & 11 & & \\
\hline & 11 & 66 & S3 & Radiculopathy & $\mathrm{T} 8$ & Incomplete laminectomy & 2.6 & 2.8 & & $\begin{array}{l}\text { Excessive bleeding. } \\
\text { Incomplete } \\
\text { laminectomy }\end{array}$ \\
\hline $\begin{array}{l}\text { Akash et al. } \\
\text { (2019) [30] }\end{array}$ & 6 & $<60$ & $\mathrm{SH}$ & Pain & $\mathrm{T}$ & Radiotherapy & 30 & 33.4 & & \\
\hline $\begin{array}{l}\text { Chandra et al. } \\
\text { (2018) [31] }\end{array}$ & 32 & 17 & $\mathrm{SH}$ & $\begin{array}{l}\text { Pain, Myelopathy, } \\
\text { Radiculopathy }\end{array}$ & $\mathrm{T7}$ & $\begin{array}{l}\text { Laminectomy, alcohol } \\
\text { injection }\end{array}$ & 2.5 & 2 & & \\
\hline \multirow[t]{2}{*}{$\begin{array}{l}\text { Cloran et al. } \\
(2015)[4]\end{array}$} & 1 & 23 & S3 & $\begin{array}{l}\text { Pain, } \\
\text { Radiculopathy }\end{array}$ & L5、S1-2 & TA, decompression & 1 & 1 & & \\
\hline & 15 & 73 & $\mathrm{S3}$ & $\begin{array}{l}\text { Pain, } \\
\text { Radiculopathy }\end{array}$ & L1 & Corpectomy & 10 & 10 & & \\
\hline $\begin{array}{l}\text { Eichberg et al. } \\
\text { (2017) [32] }\end{array}$ & 7 & 52 & S3 & Paraparesis & $\mathrm{T7}$ & Decompression & 3.6 & 1 & 2600 & Excessive bleeding \\
\hline \multirow[t]{3}{*}{$\begin{array}{l}\text { Goldstein } \\
\text { et al.(2015) [9] }\end{array}$} & & 39 & $\mathrm{SH}$ & Pain & L5 & $\begin{array}{l}\text { Intralesional excision and } \\
\text { adjuvant radiotherapy }\end{array}$ & 3.9 & 4.4 & & \\
\hline & & 50 & $\mathrm{SH}$ & Pain & T6-T8 & $\begin{array}{l}\text { Intralesional excision } \\
\text { without } \\
\text { adjuvantradiotherapy }\end{array}$ & 3.9 & 5.3 & & \\
\hline & & 39 & S3 & Pain, Paraparesis & T6 & $\begin{array}{l}\text { TA, laminectomy and } \\
\text { intralesional tumor } \\
\text { debulking }\end{array}$ & 13.5 & 5 & & \\
\hline $\begin{array}{l}\text { Hekster et al. } \\
\text { (1972) [18] }\end{array}$ & & 61 & S3 & Paraparesis & $\mathrm{T7}$ & lamineetorny & & 3 & & Excessive bleeding \\
\hline \multirow[t]{3}{*}{$\begin{array}{l}\text { Jiang et al. } \\
\text { (2014) [10] }\end{array}$} & 12 & 24 & S3 & Myelopathy & $\mathrm{T7}$ & Spondylectomy & 4.5 & 1.2 & & $\begin{array}{l}\text { Excessive bleeding } \\
\text { Without radiotherapy }\end{array}$ \\
\hline & 13 & 37 & S3 & Pain, Myelopathy & T10 & Decompression & 4.4 & 1 & & Without radiotherapy \\
\hline & 22 & 55 & $\mathrm{S3}$ & Myelopathy & T4-6 & laminectomy & 10.8 & 9 & & Without radiotherapy \\
\hline $\begin{array}{l}\text { Kato et al. } \\
(2010) \text { [12] }\end{array}$ & 2 & 51 & $\mathrm{~S} 3$ & Pain, Paraparesis & $\mathrm{T} 4$ & Decompression & 24 & 14 & 1580 & \\
\hline $\begin{array}{l}\text { Mayank et al. } \\
\text { (1999) [33] }\end{array}$ & 5 & 35 & $\mathrm{SH}$ & $\begin{array}{l}\text { Paraparesis, } \\
\text { Myelopathy }\end{array}$ & $\mathrm{T7}$ & Alcohol ablation & 2.0 & 0.1 & & \\
\hline $\begin{array}{l}\text { Urrutia et al. } \\
\text { (2011) [11] }\end{array}$ & 1 & 14 & S3 & Radiculopathy & $\mathrm{T} 12$ & Decompression & 2.0 & 1.25 & & \\
\hline $\begin{array}{l}\text { Wang et al. } \\
(2017)[34]\end{array}$ & & & S3 & & & Decompression & 5.3 & 5.4 & & \\
\hline $\begin{array}{l}\text { Wang et al. } \\
\text { (2018) [14] }\end{array}$ & & 16 & S3 & Radiculopathy & $\mathrm{T} 10$ & Incomplete vertebrectomy & 4 & 0.4 & & \\
\hline
\end{tabular}


loss was as high as $2420 \mathrm{ml}$ (range $=1580-3400 \mathrm{ml}$ ), and the average surgery duration was $608 \mathrm{~min}$ (range $=480$ $700 \mathrm{~min}$ ). Goldson et al. [9] found that although hemangiomas were aggressive, their biological properties were benign, and they did not require en bloc resection to achieve a clear surgical margin. According to the current literature [24-27], pregnant patients are prone to hemangioma recurrence because of the significant elevation of vascular endothelial growth factor (VEGF) during pregnancy [28]. The invasiveness of hemangiomas may be related to VEGF, and the bone tissue of elderly patients has less VEGF [29]. Therefore, we recommend that en bloc resection surgery be not required for elderly patients.

Vertebral decompression drastically reduces intraoperative blood loss and technical requirements; however, it has a relatively high postoperative tumor recurrence rate. Acora et al. [2] examined 22 patients with S3 aggressive hemangiomas and found that 6 patients underwent simple decompression surgery, and two had recurrence rates of $33.3 \%$. In a multicenter study, Goldson et al. [9] found that of 68 patients undergoing simple decompression surgery, three had tumor recurrence after surgery. Because the inclusion criterion of the Goldson et al. [9] study was symptomatic hemangioma (and not S3 aggressive hemangioma), it should not be directly compared with Acora et al. [3]. Additionally, this recurrence rate is acceptable because only three of 68 patients with symptomatic hemangiomas showed recurrence. In the reviewed literature (Table 4), we also found that only three elderly patients had tumor recurrence after decompression surgery. From the cases included in Acosta et al. [2] and Hekster et al. [18], we learned that the cause of recurrence was incomplete clearance of the intravertebral tumor due to the large amount of intraoperative blood loss where only the portion that compressed the spinal canal was removed. As early as 1995, Cotton et al. [35] reported the use of intraoperative bone cement to stabilize the spine. Wang et al. [14] showed that the use of bone cement to treat S3 aggressive hemangiomas significantly reduced intraoperative blood loss and postoperative recurrence. In that study, patients who received bone cement during the surgery had no recurrence. Moreover, with the recent rise of polymethyl methacrylate (PMMA) in patients undergoing decompression and resection, the intraoperative injection of bone cement might further reduce intraoperative blood loss [36]. However, some studies have also reported the risks of bone cement leakage $[35,37,38]$. In this study, we first proposed that the infusion of $1.0 \mathrm{~mm} \times 1.0 \mathrm{~mm} \times$ $1.0 \mathrm{~mm}$ absorbable gelatin sponge particles prior to the injection of bone cement might effectively reduce blood loss and provide a clearer visual field for surgery. Absorbable gelatin sponge embolization of venous channels before cement injection has not been widely used as a technique to prevent leakage. However, routine absorbable gelatin sponge embolization has been shown to be a safe and feasible method during vertebroplasty [39]. Absorbable gelatin sponge infusion prior to bone cement might effectively reduce the leakage of bone cement into the soft tissue, especially for patients with ruptured posterior vertebral body walls. Furthermore, absorbable gelatin sponge significantly reduces intraoperative blood loss and surgical duration compared with patients without absorbable gelatin sponge treatment.

Additionally, we believe that invasiveness was relatively poor among elderly patients with aggressive hemangiomas. Our literature review showed that the entirety of tumor clearance and the clarity of the intraoperative visual field were also factors affecting tumor recurrence. Therefore, we believe that decompression is sufficient for elderly patients, en bloc resection is not necessary to prevent tumor recurrence, and preoperative embolization should be used whenever possible in the clinic.

This single-center, retrospective study had a small sample size. Long-term prospective studies with larger samples are required for more detailed clinical staging and data evaluation of patients with aggressive vertebral hemangioma.

\section{Conclusions}

Multimodal treatment significantly alleviates the clinical symptoms of elderly patients with aggressive hemangiomas. The intraoperative injection of absorbable gelatin sponge may be a safe and effective method to reduce blood loss and surgery duration. The recurrence of aggressive hemangioma might be associated with aging.

\section{Abbreviations}

BMI: body mass index; CT: computed tomography; Group A: decompression combined with intraoperative vertebroplasty; Group B: decompression combined with intraoperative vertebroplasty and absorbable gelatin sponge; MRI: magnetic resonance imaging.; S1: Enneking stage 1; S2: Enneking stage 2; S3: Enneking stage 3; VAS: visual analogue scale

\section{Acknowledgements \\ The authors would like to thank Rao Hongming for her help with the data collection.}

\section{Authors' contributions \\ $\mathrm{YH}$ was responsible for patient selection and recruitment and drafting the manuscript; WX was responsible for designing the study, carrying out the surgical procedures and critically revising the manuscript; ZL was responsible for statistical analysis. All authors have read and approved the manuscript.}

\section{Funding}

No external funding.

\section{Availability of data and materials}

All data generated or analyzed during this study are available upon reasonable request from the corresponding author.

Ethics approval and consent to participate

This study was approved by the Ethics Committee at Fuzhou Second Hospital Affiliated to Xiamen University (approval No: FZSE2018-10-20 037). 
All the patients gave written consent to for research applications of their clinical data.

\section{Consent for publication}

All participants gave written consent on the publication of anonymized data.

\section{Competing interests}

The authors declare that they have no competing interests.

\section{Author details}

${ }^{1}$ Department of Spine Surgery, First Affiliated Hospital of Fujian Medical University, Fuzhou 350004, Fujian, China. ²Department of Spine Surgery, Quanzhou Orthopedic-Traumatological Hospital of Fujian Traditional Chinese Medicine University, Quanzhou 362000, Fujian, China. ${ }^{3}$ The Orthopedics Department, Fuzhou Second Hospital affiliated to Xiamen University, Cangshan District, Fuzhou 350007, Fujian, China.

\section{Received: 16 November 2019 Accepted: 17 February 2020 Published online: 24 February 2020}

\section{References}

1. Enneking WF. A system of staging musculoskeletal neoplasms. Clin Orthop Relat Res. 1986;204:9-24.

2. Acosta FJ, Sanai N, Chi JH, Dowd CF, Chin C, Tihan T, Chou D, Weinstein PR, Ames CP. Comprehensive management of symptomatic and aggressive vertebral hemangiomas. Neurosurg Clin N Am. 2008;19(1):17-29.

3. Acosta FJ, Sanai N, Cloyd J, Deviren V, Chou D, Ames CP. Treatment of Enneking stage 3 aggressive vertebral hemangiomas with intralesional spondylectomy: report of 10 cases and review of the literature. J Spinal Disord Tech. 2011;24(4):268-75.

4. Cloran FJ, Pukenas BA, Loevner LA, Aquino C, Schuster J, Mohan S. Aggressive spinal haemangiomas: imaging correlates to clinical presentation with analysis of treatment algorithm and clinical outcomes. Br J Radiol. 2015;88(1055):20140771.

5. Gaudino S, Martucci M, Colantonio R, Lozupone E, Visconti E, Leone A Colosimo C. A systematic approach to vertebral hemangioma. Skelet Radiol. 2015:44(1):25-36.

6. Blecher R, Smorgick Y, Anekstein Y, Peer A, Mirovsky Y. Management of symptomatic vertebral hemangioma: follow-up of 6 patients. J Spinal Disord Tech. 2011;24(3):196-201.

7. Dang L, Liu C, Yang SM, Jiang L, Liu ZJ, Liu XG, Yuan HS, Wei F, Yu M. Aggressive vertebral hemangioma of the thoracic spine without typical radiological appearance. Eur Spine J. 2012;21(10):1994-9.

8. Dobran M, Mancini F, Nasi D, Gladi M, Sisti S, Scerrati M. Surgical treatment of aggressive vertebral hemangioma causing progressive paraparesis. Ann Med Surg (Lond). 2018;25:17-20.

9. Goldstein CL, Varga PP, Gokaslan ZL, Boriani S, Luzzati A, Rhines L, Fisher CG, Chou D, Williams RP, Dekutoski MB, et al. Spinal hemangiomas: results of surgical management for local recurrence and mortality in a multicenter study. Spine (Phila Pa 1976). 2015;40(9):656-64.

10. Jiang L, Liu XG, Yuan HS, Yang SM, Li J, Wei F, Liu C, Dang L, Liu ZJ. Diagnosis and treatment of vertebral hemangiomas with neurologic deficit: a report of 29 cases and literature review. Spine J. 2014;14(6):944-54.

11. Urrutia J, Postigo R, Larrondo R, Martin AS. Clinical and imaging findings in patients with aggressive spinal hemangioma requiring surgical treatment. J Clin Neurosci. 2011;18(2):209-12.

12. Kato S, Kawahara N, Murakami H, Demura S, Yoshioka K, Okayama T, Fujita T, Tomita K. Surgical management of aggressive vertebral hemangiomas causing spinal cord compression: long-term clinical follow-up of five cases. Orthop Sci. 2010;15(3):350-6.

13. Delabar V, Bruneau M, Beuriat PA, Zairi F, Fuentes S, Riva R, Gory B, Barrey C. The efficacy of multimodal treatment for symptomatic vertebral hemangiomas: a report of 27 cases and a review of the literature. Neurochirurgie. 2017:63(6):458-67.

14. Wang B, Han SB, Jiang L, Liu XG, Yang SM, Meng N, Wei F, Liu ZJ. Intraoperative vertebroplasty during surgical decompression and instrumentation for aggressive vertebral hemangiomas: a retrospective study of 39 patients and review of the literature. Spine J. 2018;18(7):1128-35.

15. Eichberg DG, Starke RM, Levi AD. Combined surgical and endovascular approach for treatment of aggressive vertebral haemangiomas. $\mathrm{Br} J$ Neurosurg. 2018;32(4):381-8.
16. Zhang HL, Hu YC, Aryal R, He X, Lun DX, Zhao LM. Thoracic vertebral Hemangioma with spinal cord compression: multidisciplinary surgical treatment and follow-up of six patients. Orthop Surg. 2016;8(4):462-7.

17. Heyd R, Seegenschmiedt MH, Rades D, Winkler C, Eich HT, Bruns F, Gosheger G, Willich N, Micke O. Radiotherapy for symptomatic vertebral hemangiomas: results of a multicenter study and literature review. Int J Radiat Oncol Biol Phys. 2010;77(1):217-25.

18. Hekster RE, Luyendijk W, Tan TI. Spinal-cord compression caused by vertebral haemangioma relieved by percutaneous catheter embolisation. Neuroradiology. 1972;3(3):160-4.

19. Chen HI, Heuer GG, Zaghloul K, Simon SL, Weigele JB, Grady MS. Lumbar vertebral hemangioma presenting with the acute onset of neurological symptoms. Case report. J Neurosurg Spine. 2007;7(1):80-5.

20. Cianfoni A, Massari F, Dani G, Lena JR, Rumboldt Z, Vandergrift WA, Bonaldi G. Percutaneous ethanol embolization and cement augmentation of aggressive vertebral hemangiomas at two adjacent vertebral levels. J Neuroradiol. 2014:41(4):269-74.

21. Boschi V, Pogorelic Z, Gulan G, Perko Z, Grandic L, Radonic V. Management of cement vertebroplasty in the treatment of vertebral hemangioma. Scand J Surg. 2011;100(2):120-4.

22. Robinson $Y$, Sheta R, Salci K, Willander J. Blood loss in surgery for aggressive vertebral Haemangioma with and without embolisation. Asian Spine J. 2015;9(3):483-91.

23. Ogawa R, Hikata T, Mikami S, Fujita N, Iwanami A, Watanabe K, Ishii K, Nakamura M, Toyama Y, Matsumoto M. Total en bloc spondylectomy for locally aggressive vertebral hemangioma causing neurological deficits. Case Rep Orthop. 2015;2015:724364.

24. Demirkale I, De lure F, Terzi S, Gasbarrini A. Aggressive hemangioma of the spine in a pregnant female: a case report and literature review. Eklem Hastalik Cerrahisi. 2016:27(1):46-50.

25. Kiroglu Y, Benek B, Yagci B, Cirak B, Tahta K. Spinal cord compression caused by vertebral hemangioma being symptomatic during pregnancy. Surg Neurol. 2009;71(4):487-92 492

26. Redekop GJ, Del MR. Vertebral hemangioma causing spinal cord compression during pregnancy. Surg Neurol. 1992;38(3):210-5.

27. Vijay K, Shetty AP, Rajasekaran S. Symptomatic vertebral hemangioma in pregnancy treated antepartum. A case report with review of literature. Eur Spine J. 2008:17(Suppl 2):S299-303.

28. Torry DS, Holt VJ, Keenan JA, Harris G, Caudle MR, Torry RJ. Vascular endothelial growth factor expression in cycling human endometrium. Fertil Steril. 1996;66(1):72-80.

29. Anagnostouli M, Katsavos S, Kyrozis A, Gontika M, Voumvourakis Kl, Kapaki E. Vertebral hemangiomas in the thoracic spine of multiple sclerosis patients are connected with fewer demyelinating lesions at the same level. Possible impact on pathophysiology and clinical course. Neurol Res 2016;38(8):655-62.

30. Parekh AD, Amdur RJ, Mendenhall WM, Morris CG, Zlotecki RA. Long-term Tumor Control With Radiotherapy for Symptomatic Hemangioma of a Vertebral Body. Spine (Phila Pa 1976). 2019:44(12):E731-E734

31. Chandra SP, Singh P, Kumar R, Agarwal D, Tandon V, Kale SS, Sarkar C. Long-term outcome of treatment of vertebral body hemangiomas with direct ethanol injection and short-segment stabilization. Spine J. 2019:19(1):131-43.

32. Eichberg DG, Starke RM, Levi AD. Combined surgical and endovascular approach for treatment of aggressive vertebral haemangiomas. $\mathrm{Br} J$ Neurosurg. 2018;32(4):381-88

33. Goyal M, Mishra NK, Sharma A et al. Alcohol ablation of symptomatic vertebral hemangiomas. AJNR Am J Neuroradiol. 1999;20(6):1091-6

34. Wang B, Meng N, Zhuang $\mathrm{H}$ et al. The Role of Radiotherapy and Surgery in the Management of Aggressive Vertebral Hemangioma: A Retrospective Study of 20 Patients. Med Sci Monit. 2018;24:6840-50.

35. Cotten A, Deramond $H$, Cortet $B$, Lejeune JP, Leclerc $X$, Chastanet $P$, Clarisse J. Preoperative percutaneous injection of methyl methacrylate and N-butyl cyanoacrylate in vertebral hemangiomas. AJNR Am J Neuroradiol. 1996;17(1):137-42.

36. Tarantino R, Donnarumma P, Nigro L, Delfini R. Surgery in extensive vertebral hemangioma: case report, literature review and a new algorithm proposal. Neurosurg Rev. 2015:38(3):585-92 592

37. Liu XW, Jin P, Wang LJ, Li M, Sun G. Vertebroplasty in the treatment of symptomatic vertebral haemangiomas without neurological deficit. Eur Radiol. 2013;23(9):2575-81. 
38. Premat K, Clarencon F, Cormier E, Mahtout J, Bonaccorsi R, Degos V, Chiras J. Long-term outcome of percutaneous alcohol embolization combined with percutaneous vertebroplasty in aggressive vertebral hemangiomas with epidural extension. Eur Radiol. 2017;27(7):2860-7.

39. Bhatia C, Barzilay Y, Krishna M, Friesem T, Pollock R. Cement leakage in percutaneous vertebroplasty: effect of preinjection gelfoam embolization. Spine (Phila Pa 1976). 2006;31(8):915-9.

\section{Publisher's Note}

Springer Nature remains neutral with regard to jurisdictional claims in published maps and institutional affiliations.

Ready to submit your research? Choose BMC and benefit from:

- fast, convenient online submission

- thorough peer review by experienced researchers in your field

- rapid publication on acceptance

- support for research data, including large and complex data types

- gold Open Access which fosters wider collaboration and increased citations

- maximum visibility for your research: over $100 \mathrm{M}$ website views per year

At BMC, research is always in progress.

Learn more biomedcentral.com/submissions 